\title{
The Interplay between the Psychological Factors and Entrepreneurial Intention: An Empirical Investigation
}

\author{
Mir Abdullah SHAHNEAZ ${ }^{1}$, Mohammad Bin AMIN ${ }^{2}$, Lima Nasrin ENI ${ }^{3}$
}

Received: September 01, 2020 Revised: October 26, 2020 Accepted: November 05, 2020

\begin{abstract}
The domain of entrepreneurship has been dotted across various paradigms. Identifying and examining entrepreneurial intention and propensity to it spontaneously require the insight from the lens of psychological approach. The aim of this study is to examine the influence and impact of psychological factors on entrepreneurial intention; as it is found that in Bangladeshi context several entrepreneurship studies are undertaken, still the exploratory research on interplay between the psychological factors (i.e., self-confidence, locus of control, need for achievement, and tolerance for ambiguity) and entrepreneurial intention has been merely found. The study has chosen Bangladeshi university students as the unit of analysis and the ultimate sample size in this research is $n=265$. The current paper is a quantitative study where sampling method is followed by convenience sampling technique, and study data is collected through survey questionnaire. Data has been compiled into SPSS whereas, for hypotheses assessment, Smart PLS software is applied. The results reflect that self-confidence, locus of control, and need for achievement are revealed as contributory determinants of entrepreneurial intention while tolerance for ambiguity is found as an insignificant predictor. The current research is expected to offer an in-depth understanding about the significance of psychological factors in examining entrepreneurial intention.
\end{abstract}

Keywords: Entrepreneurial Intention, Self-confidence, Tolerance for Ambiguity, Locus of Control, Need for Achievement

JEL Classification Code: M12, M13, M21

\section{Introduction}

These days, Bangladesh is considered one of the developing and emerging economies (Akhter et al., 2020). It is observed that Bangladesh has experienced a growing rate of GDP over the past couple of years; still everincreasing trend of unemployment remains a reoccurring problem for research scholars and policymakers (Hossain et al., 2020). A considerable percentage of unemployed

${ }^{1}$ First Author. Assistant Professor, Department of Business Administration, Shanto-Mariam University of Creative Technology, Dhaka, Bangladesh. Email: major.navana@yahoo.com

${ }^{2}$ Corresponding Author. Associate Professor, Department of Business

Administration, Bangladesh Army University of Science \& Technology,

Saidpur Cantonment, Rangpur, Bangladesh [Postal Address: Saidpur

Cantonment, Nilphamari, Rangpur, 5310, Bangladesh]

Email: binamindu@gmail.com

${ }^{3}$ Lecturer, Department of Business Administration, Bangladesh Army University of Science \& Technology, Saidpur Cantonment, Rangpur, Bangladesh. E-mail: limanasrin17@gmail.com

(c) Copyright: The Author(s)

This is an Open Access article distributed under the terms of the Creative Commons Attribution Non-Commercial License (https://creativecommons.org/licenses/by-nc/4.0/) which permits unrestricted non-commercial use, distribution, and reproduction in any medium, provided the original work is properly cited. population is Bangladeshi graduate students (Hossain et al., 2019). Therefore, encouragement and advancement of entrepreneurial projects and tasks could be regarded as a possible solution to counter the upward trend of unemployment in Bangladesh, as empirical development of entrepreneurship works as a crucial driver of employment creation within an economy (Barba-Sánchez \& AtienzaSahuquillo, 2018). Also, entrepreneurial activities enhance the quality of welfare maximization within the social system through creating more jobs for the people. Entrepreneurial people are perceived to be contributors to the country's development momentum by developing and nurturing profitable and flourishing business ventures. It has been reported that entrepreneurship development crucially adds value to the country's economic growth (Ezeh et al., 2019 and Vuong et al., 2020). Nowadays, entrepreneurship is notably viewed as an alternative career option by the graduating students as the current young population indicates a serious appetite and passion for entrepreneurial venture on a global context. Furthermore, the conducive role of entrepreneurship is treated as a center of research hub among the academics in the world (Wardana et al., 2020). At the same time, from the scholarly viewpoint, a greater level of academic research 
interest is linked with entrepreneurial intention (EI); EI is believed to be the earliest and fundamental period for developing entrepreneurship, which would essentially point an individual's inclination to come up with his or her own self-employment entrepreneurial business (Nowiński \& Haddoud, 2019). As it is critically important to gauge and examine entrepreneurial intention, which is indicative of furthering entrepreneurial activities, hence this context proposes an empirical investigation to identify and examine the factors that might drive student's eagerness and inclination towards entrepreneurship.

Imperatively, taking into account student's inclination and intention can be a representative sample to investigate EI in an emerging country context like Bangladesh. Students face their immediate employment option after their graduation, and entrepreneurship is chosen as a panacea to employment option for the students; hence, it would be pertinent to understand what variables or factors drive their intention to start entrepreneurial business (Nguyen, 2018). A number of entrepreneurship-related studies have examined the antecedents and determinants of EI, while taking students as their sample population. Although some research has investigated the impact of student's psychological factors on theirintention towardentrepreneurship, stillvery littleresearch has been conducted to understand whether psychological variables drive student's entrepreneurial intention (EI) from Bangladesh perspective. In Bangladesh, entrepreneurship studies focused extensively on the advancement of and barriers to entrepreneurship development, still a lucid comprehension of how psychological characteristically factors influence student's EI is hardly found in the entrepreneurship literature. Psychological traits of a person have been immensely significant in regulating and shaping entrepreneurial behaviors (Ferreira et al., 2012), therefore, this study seeks to investigate the interplay between students' psychological factors (i.e., self-confidence, locus of control, need for achievement, and tolerance for ambiguity) and their intention to start entrepreneurial venture, from a Bangladeshi perspective.

\section{Literature Review and Hypothesis Development}

\subsection{Entrepreneurial Intention (EI)}

Entrepreneurship is described as "the creation of new enterprise" by Low and MacMillan (1988). Entrepreneurship focuses on founding a business venture with taking essential actions, which are relevant to the overall busines ecosystem. Entrepreneurship can be illustrated as a pursuit that underpins the assessment and utilization of opportunities (Güven, 2009). The development of entrepreneurship starts when a person chooses to take on a new business (Karimi et al., 2017). Entrepreneurship facilitates a greater array of research attention over few decades in various domains of study because of its vital significance for a nation's economic development (Urbano \& Aparicio, 2016). In academic literature on entrepreneurship, various streams of research have come to light, in which studies of entrepreneurial intention (EI) remains salient because of the urgency to foster entrepreneurial ventures among the prospective individuals (Córcoles-Muñoz et al., 2019). The term "intention" is derived from the domain of cognitive psychology to anticipate and envisage human behavioral action (Quan, 2012). Intention toward entrepreneurship is perceived to be a powerful determinant of starting own entrepreneurial business by an individual (Hossain \& Asheq, 2020). According to Ajzen (1987), intention could be critical in predicting human behaviors. Intention is conceived to be a psychological stage of an individual that reflects his or her propensity to attain a desired goal. Henley (2007) argued that entrepreneurship development has been regarded as a person's purposeful and intentional activity. It is reported that persons who have entrepreneurial intention, they are more likely to adopt necessary actions to start a new business (Prodan \& Drnovsek, 2010). Entrepreneurial intention reflects the designing and carrying out business ideas that follows the mental activity of a person (Gupta \& Bhawe, 2007). It is important to scrutinize EI at the time of forecasting entrepreneurial behavior (Gerba, 2012).

\subsection{Psychological Factors and EI}

The current study examines psychological factors to study EI. Several studies adopted this psychological approach to examine entrepreneurship and EI. For example, Churchill and Bygrave (1989) proposed a model of psychological approach to study EI, in which they included achievement orientation, risk taking, locus of control, and tolerance for ambiguity as factors of psychological approach. Again, Robinson et al. (1991) proposed a model of psychological approach that includes achievement, innovativeness, and self-confidence, which could be determining factors of EI. In the literature, it is found that need for achievement, locus of control, tolerance for ambiguity, and self-confidence were considered as core psychological factors to study entrepreneurship and EI. Considering these four variables as psychological factors, the following sub-sections describe the relationship between psychological factors and EI and propose hypotheses based on prior research.

\subsection{Locus of Control (LA) and EI}

Locus of control refers to a person's faith and belief of what controls and administers human fortune and failure 
Mir Abdullah SHAHNEAZ, Mohammad Bin AMIN, Lima Nasrin ENI /

in their life (Hossain et al., 2019). Locus of control was first proposed by Rotter (1966), who clarifies that locus of control directs a person to trust that the end result of an incident is the outcome of his/her behavioral activity rather than perceiving the outcome as a result of luck. Robinson et al. (2013) argued that locus of control is related with positive entrepreneurial actions. Locus of control significantly triggers the students' entrepreneurial intention (Sesen, 2013). Thus, it is hypothesized that:

H1: Locus of control (LC) of students has positive effect on their EI.

\subsection{Need for Achievement (NA) and EI}

The concept of "Need for Achievement" was first developed by McClelland (1961), in which he indicated that a positive connectivity exited between need for achievement and development of entrepreneurial venture. This concept generally indicates a person's yearning for significant achievement (Zeffane, 2013). Several studies persistently found a positive association between need for achievement and entrepreneurial activities (Collins et al., 2004; Segal et al., 2007). A study on US small business managers reported that entrepreneurial managers showed a greater penchant for business achievement (Stewart et al., 1999). Also, need for achievement is perceived to drive a person's eagerness and desire to enhance his/her performance and to drive for success in the business domain (Loon \& Casimir, 2008). Based on prior studies, this study has found that need for achievement positively affected student's entrepreneurial intention. Thus, it is hypothesized that

H2: Need for achievement (NA) of students has positive effect on their EI.

\subsection{Self-confidence (SC) and EI}

Self-confidence is one of the indispensable assets for a person that really helps in reaching successful achievement (Gelaidan \& Abdullateef, 2017). The concept of "selfconfidence" has been explained as a person's faith in his or her capability to plan and accomplish a particular project, which is essential to obtain desired outcomes (Nasip et al., 2017). Having greater self-confidence is extensively recommended as a core characteristic of an entrepreneur (Dinis et al., 2013). According to Burns (2008), self-confidence is a paramount element with a view to tackling the uncertain situation and initiating own venture. Robinson et al. (1991) showed that self-confidence has been a distinguishable characteristic of entrepreneurs, which would differentiate them from nonentrepreneurial people in business environment. Mathieu and St-Jean (2013) argued that entrepreneurship is such kind of initiative that would demand higher extent of selfconfidence. It was also suggested in past studies that selfconfidence was positively inter- linked with EI. Hence, it is proposed that

H3: Self-confidence (SC) of students has positive effect on their EI.

\subsection{Tolerance for ambiguity (TA) and EI}

Tolerance for ambiguity can be described as the inclination to scan and observe environment without clear consequence as lucrative rather than alarming (Budner, 1982). Tolerance for ambiguity refers to the capability of a person to encounter and withstand an ambiguous and uncertain situation (Nasip et al., 2017). People with high tolerance for ambiguity level are supposed to perform better in unstructured and unpredictable circumstances. The study by Gurel et al. (2010) indicated that people with tolerance for ambiguity are found to be more active in creating new businesses. It is also claimed that tolerance for ambiguity can be viewed as an attributable element of an entrepreneurial characteristics, and entrepreneurial individual is supposed to exhibit relatively higher tolerance for ambiguity than other population (Dinis et al., 2013). Moreover, Zarei et al. (2013), in their study on university students, found that tolerance for ambiguity has been connected with the dimension of entrepreneurial activities. A contemporary study in Malaysian context has also revealed that young people' intention for starting entrepreneurial venture is stimulated by tolerance for ambiguity (Tateh et al., 2014). Thus, it is hypothesized that

H4: Tolerance for ambiguity (TA) of students has positive effect on their EI.

\section{Methodology}

The overall aim of the study is to identify the impact of psychological variables on EI of Bangladeshi university students. Hence, the sample for this research has been drawn from the Bangladeshi universities where bachelor and master's degree students are currently studying. The study has applied a self-executed or administered survey questionnaire that is formulated based on relevant past research studies. Convenience technique, which is a non-probability sampling method, has been used to gather the data from students. The study is exploratory and quantitative in nature. Survey questionnaires were randomly given to the students with instructions and, then, collected. The survey form has two sections: the first section refers to the general information about the students such as their name, age, gender, and department; the second section refers to the Likert scale- 
measured questions based on the entrepreneurial intention, self-confidence, locus of control, tolerance for ambiguity, and need for achievement. A 5-point Likert scale is used, where 1 means "firmly agree" and 5 means "firmly disagree". In this study, dependent and independent variables (IV) have been adopted from Dinis (2013) study. Out of a total 340 survey questionnaires distributed among the university bachelor and master degree students, 265 responses were found appropriate and complete. In this regard, Roscoe (1975) suggested that a minimum sample size of 30 to a maximum of 500 might be appropriate for a quantitative study. Therefore, the final sample size in this study is $n=265$.

\section{Results and Discussion}

\subsection{Sample Profile}

Table 1 contains the basic demographic information of the university students who took part in this study as respondents. Out of 265 students, 188 are male, while 77 are female. In terms of age distribution, nearly $50 \%$ (131) of the respondents are between 18 and 20 years old, which indicates that half of the respondents are very young. Some $26 \%$ (69) are between 21 and 25 years; $15.5 \%$ (41) are between 26 and 30; 6.8\% (18) are between 31 and 40; and 2.3\% (6) are over 40. In this study, the majority of the university students are in the Business Administration department (71.3\%), while 16.6 (44) of the students are studying in the Social Sciences department. Also, 117 (44.2\%) students are in the first year of their bachelor degree, $51(19.2 \%)$ students are in the second year, $35(13.2 \%)$ students are in the third year, $34(12.8 \%)$ students are in the final year, and $28(10.6 \%)$ students are in the master degree level. Table 1 showed the demographic profile of the study:

\subsection{Measurement Model}

In this stage, the researchers conducted confirmatory factor analysis (CFA) to assess the factor structure, reliability, and validity of the measurement model. Statistical analysis is conducted through Smart PLS version 2.0. The study performed confirmatory factor analysis to test reliability and validity of study constructs (Table 2). Reliability is assessed through considering composite reliability (CR), and construct validity is measured through item loadings and AVE scores. The general acceptable minimum threshold value for each item loadings is required to be more than 0.60 , for AVE $>0.50$, and for CR $>0.70$ (Chin, 2010).

Table 1: Demographic Profile

\begin{tabular}{|l|c|c|}
\hline Description (n=265) & Frequency & Percentage (\%) \\
\hline Gender & & 70.9 \\
\hline Male & 188 & 29.1 \\
\hline Female & 77 & 49.4 \\
\hline Age of the respondents & 131 & 26.0 \\
\hline 18 to 20 years & 69 & 15.5 \\
\hline 21 to 25 years & 41 & 6.8 \\
\hline 26 to 30 years & 18 & 2.3 \\
\hline 31 to 40 years & 6 & 71.3 \\
\hline$>40$ years & & 16.6 \\
\hline Academic Department & 189 & 12.1 \\
\hline Department of Business Administration & 44 & \\
\hline Department of Social Science & 32 & 44.2 \\
\hline Department of Science \& Engineering & & 19.2 \\
\hline Year of Education & 117 & 13.2 \\
\hline First year & 51 & 12.8 \\
\hline Second year & 35 & 10.6 \\
\hline Third year & 34 & 28 \\
\hline Final year & & \\
\hline Master/MBA & & \\
\hline
\end{tabular}


Mir Abdullah SHAHNEAZ, Mohammad Bin AMIN, Lima Nasrin ENI /

Table 2: Measurement Model Assessment Using CFA

\begin{tabular}{|c|c|c|c|c|c|}
\hline Construct & Item Codes & Item Loadings & AVE & CR & Cronbach's Alpha \\
\hline \multirow{6}{*}{$\begin{array}{l}\text { Entrepreneurial } \\
\text { Intention (EI) }\end{array}$} & El1 & 0.759 & 0.524 & 0.767 & 0.643 \\
\hline & $\mathrm{El} 2$ & 0.7609 & & & \\
\hline & $\mathrm{EI} 3$ & 0.6962 & & & \\
\hline & El4 & 0.7584 & & & \\
\hline & El5 & 0.7609 & & & \\
\hline & EI6 & 0.6458 & & & \\
\hline \multirow{5}{*}{$\begin{array}{l}\text { Locus of } \\
\text { Control (LC) }\end{array}$} & LC1 & 0.7028 & 0.566 & 0.867 & 0.870 \\
\hline & LC2 & 0.8136 & & & \\
\hline & LC3 & 0.7973 & & & \\
\hline & LC4 & 0.7543 & & & \\
\hline & LC5 & 0.6848 & & & \\
\hline \multirow{5}{*}{$\begin{array}{l}\text { Need for Achievement } \\
\text { (NA) }\end{array}$} & NA1 & 0.7548 & 0.505 & 0.835 & 0.757 \\
\hline & NA2 & 0.7518 & & & \\
\hline & NA3 & 0.6359 & & & \\
\hline & NA4 & 0.7226 & & & \\
\hline & NA5 & 0.6791 & & & \\
\hline \multirow{5}{*}{ Self Confidence (SC) } & SC1 & 0.7751 & 0.584 & 0.875 & 0.821 \\
\hline & $\mathrm{SC} 2$ & 0.7649 & & & \\
\hline & SC3 & 0.7853 & & & \\
\hline & SC4 & 0.7936 & & & \\
\hline & SC5 & 0.6967 & & & \\
\hline \multirow{5}{*}{$\begin{array}{l}\text { Tolerance for } \\
\text { Ambiguity (TA) }\end{array}$} & TA1 & 0.6657 & 0.512 & 0.840 & 0.771 \\
\hline & TA2 & 0.6681 & & & \\
\hline & TA3 & 0.7494 & & & \\
\hline & TA4 & 0.8105 & & & \\
\hline & TA5 & 0.675 & & & \\
\hline
\end{tabular}

Table 3: Discriminant Validity (Fornell Larcker Criterion)

\begin{tabular}{|l|c|c|c|c|c|}
\hline & EI & LC & NA & SC & TA \\
\hline EI & $\mathbf{0 . 7 2 4}$ & & & & \\
\hline LC & 0.345 & $\mathbf{0 . 7 5 2}$ & & & \\
\hline NA & 0.159 & 0.154 & $\mathbf{0 . 7 1 1}$ & & \\
\hline SC & 0.315 & 0.223 & 0.118 & $\mathbf{0 . 7 6 4}$ & \\
\hline TA & 0.272 & 0.493 & 0.105 & 0.193 & $\mathbf{0 . 7 1 6}$ \\
\hline
\end{tabular}


Table 4: Structural Model (Path Analysis)

\begin{tabular}{|l|c|c|c|c|}
\hline Paths & Unstandardized Beta & Standardized Beta & Standard Error & T Statistics \\
\hline LC -> El & 0.228 & 0.2271 & 0.102 & 2.242 \\
\hline NA -> El & 0.225 & 0.1154 & 0.103 & 2.184 \\
\hline SC -> EI & 0.233 & 0.2441 & 0.085 & 2.739 \\
\hline TA -> El & 0.106 & 0.1396 & 0.111 & 0.953 \\
\hline
\end{tabular}

NB (Table 3\&4): EI = Entrepreneurial Intention; LC = Locus of Control; NA = Need for Achievement; SC = Self Confidence; TA = Tolerance for Ambiguity

From Table 2, it can be observed that all items have fulfilled the required value score of item loadings, $\mathrm{CR}$ and AVE, hence the study's measurement model is found to be consistent with the standard criteria of convergent validity. In addition, the study also performed discriminant validity that was based on Fornell-Larcker standard (Hair et al., 2013), shown in Table 3. According to the standard of Fornell-Larcker's benchmark, the square root of the values of AVE has to be higher than the connectivity of the latent constructs of the actual non-diagonal variables. The results of CFA are also shown in Table 2.

Table 3 shows that the current research meets the requirement of discriminant validity measurement according to Fornell Larcker Criterion.

Table 4 presents the structural model or path analysis of this study; it also shows the outcome of hypotheses testing.

Explaining the analysis, H1 predicted that the locus of control (LC) would affect entrepreneurial intention (EI) of the university students, and from Table 4, it can be seen that $\mathrm{H} 1$ is accepted $(\beta=0.2271, p<0.05)$, which imply that LC significantly affects EI, and the result is in line with previous entrepreneurial studies (Prakash et al., 2015; Hossain et al., 2019). The result implies that greater level of locus of control would positively affect students' propensity and intention towards entrepreneurial activities. $\mathrm{H} 2$ proposed that the need for achievement (NA) would affect EI of the university students, and the path analysis result indicates that $\mathrm{H} 2$ is accepted $(\beta=0.1154, p<0.05)$; that points out that NA positively influences EI of the university students, and this finding is supported by past studies (Ryan et al., 2011; Zeffane, 2013). It does indicate that students who have higher need for achievement, are more likely to start their own entrepreneurial business in the future. $\mathrm{H} 3$ hypothesized that self-confidence (SC) would affect EI of the university students, and from Table 4, it can be seen that $\mathrm{H} 3$ is supported $(\beta=0.2221, p<0.05)$, meaning that SC statistically affects $\mathrm{EI}$, a result also in line with prior entrepreneurial studies (Gelaidan \& Abdullateef, 2017). H4 proposed that tolerance for ambiguity (TA) would impact EI of the students, and the model result shows that $\mathrm{H} 4$ is not accepted $(\beta=0.1396$, $p>0.05$ ); it points out that TA does not influence EI of the university students. Very few studies found that tolerance for ambiguity (TA) does not affect entrepreneurial intention (Dinis et al., 2015).

\section{Conclusions}

The current research examined and analyzed the effect of psychological factors on university students' entrepreneurial intention (EI) in Bangladesh. The study's findings reflect that locus of control (LA), need for achievement (NA), and self-confidence (SA) were found to exert a positive impact on student's EI, whereas tolerance for ambiguity (TA) did not influence students' EI in this research. Hence, it can be posited that developing these psychological characteristics of university students would be pivotal for policymakers to reduce unemployment across the country. To implement this, universities and various educational institutes may appraise the inclusion of these psychological variables at the time of developing educational curriculum and projects for the prospective students in order to generate sufficient level of zeal and fervor for entrepreneurship as a career. It could be achievable through holding symposiums and projects on entrepreneurial activities and delivering entrepreneurshiporiented periodical training to enhance students' eagerness to be an entrepreneur. Moreover, local educational institutes and development organizations need to focus on integrating psychological factors in entrepreneurship courses in their pedagogical mechanisms to advance potential students' endeavor towards entrepreneurship.

\section{References}

Ajzen, I. (1987). Attitudes, traits and actions: Dispositional prediction of behaviour in personality and social psychology. Advances in Experimental Social Psychology, 20, 1-63.

Akhter, A., Hossain, M. U. \& Asheq, A. A. (2020). Influential Factors of Social Entrepreneurial Intention in Bangladesh. Journal of Asian Finance, Economics and Business, 7(8), 645651. https://doi.org/10.13106/jafeb.2020.vo17.no8.645

Barba-Sánchez, V., \& Atienza-Sahuquillo, C. (2018). Entrepreneurial intention among engineering students: The role of 
Mir Abdullah SHAHNEAZ, Mohammad Bin AMIN, Lima Nasrin ENI /

entrepreneurship education. European Research on Management and Business Economics, 24(1), 53-61.

Budner, S. (1982). Intolerance of ambiguity as a personality variable. Journal of Personality, 30(1), 29-50.

Burns, P. (2008). Corporate Entrepreneurship: Building the Entrepreneurial Organization ( $2^{\text {nd }}$ ed.). New York, NY: Palgrave Macmillan.

Churchill, N., \& Bygrave, W. D. (1989). The Entrepreneur ship Paradigm (I): A Philosophical Look at Its Research Methodologies. Entrepreneurship Theory and practice, 14(1), 7-26.

Collins, C. J., Hanges, P. J. \& Locke, E. A. (2004). The relationship of achievement motivation to entrepreneurial behavior: A metaanalysis. Human Performance 17(1), 95-117.

Córcoles-Muñoz, M. M., Parra-Requena, G., Ruiz-Ortega, M. J., García-Villaverde, P. M., \& Ramírez-Fernández, F. J. (2019). Psychological and Biographical Determinants of Entrepreneurial Intention: Does the Learning Environment Act as a Mediator? Administrative Sciences, 9(2), 1-22.

Dinis, A., do Paço, A., Ferreira, J., Raposo, M. \& Gouveia Rodrigues, R. (2013). Psychological characteristics and entrepreneurial intentions among secondary students. Education + Training, 55(8/9), 763-780.

Ezeh, P.C., Nkamnebe, A.D. \& Omodafe, U.P. (2019). Determinants of entrepreneurial intention among undergraduates in a Muslim community. Management Research Review, 43(8), 1013-1030.

Ferreira, J. J., Raposo, M. L., Rodrigues, R. G., Dinis, A., \& Paço, A. D. (2012). A model of entrepreneurial intention: An application of the psychological and behavioral approaches. Journal of Small Business and Enterprise Development, 19(3), 424-440.

Gelaidan, H.M. \& Abdullateef, A.O. (2017). Entrepreneurial intentions of business students in Malaysia: The role of selfconfidence, educational and relation support. Journal of Small Business and Enterprise Development, 24(1), 54-67.

Gerba, D. T. (2012). Impact of entrepreneurship education on entrepreneurial intentions of business and engineering students in Ethiopia. African Journal of Economic and Management Studies, 3(2), 258-277.

Gupta, V. K., \& Bhawe, N. M. (2007). The influence of proactive personality and stereotype threat on women's entrepreneurial intentions. Journal of Leadership \& Organizational Studies, 13(4), 73-85.

Gurel, E., Altinay, L., \& Daniele, R. (2010). Tourism students' entrepreneurial intentions. Annals of Tourism Research, 37(3), 646-669.

Güven, S. (2009). New primary education course programmes and entrepreneurship. Procedia-Social and Behavioral Sciences, 1(1), 265-270.

Hair, J. F., Ringle, C. M., \& Sarstedt, M. (2013). Partial least squares structural equation modeling: Rigorous applications, better results and higher acceptance. Long Range Planning, $46(1 / 2), 1-12$.
Henley, A. (2007). Entrepreneurial aspiration and transition into self-employment: evidence from British longitudinal data. Entrepreneurship \& Regional Development, 19(3), 253-280.

Hossain, M. U., \& Asheq, A. A. (2020). Do leadership orientation and proactive personality influence social entrepreneurial intention? International Journal of Management and Enterprise Development, 19(2), 109-125.

Hossain, M. U., Asheq, A. A. \& Arifuzzaman, S. M. (2019). Entrepreneurial intention of Bangladeshi students: impact of individual and contextual factors. Problems and Perspectives in Management, 17(4), 493-503.

Karimi, S., Biemans, H. J., Naderi Mahdei, K., Lans, T., Chizari, M., \& Mulder, M. (2017). Testing the relationship between personality characteristics, contextual factors and entrepreneurial intentions in a developing country. International Journal of Psychology, 52(3), 227-240.

Loon, M. \& Casimir, G. (2008). Job-demand for learning and jobrelated learning: the moderating effect of need for achievement. Journal of Managerial Psychology, 23(1), 89-102.

Low, M. B. \& MacMillan, I.C. (1988). Entrepreneurship: past research and future challenges. Journal of Management, 14(2), 139-161.

Mathieu, C., \& St-Jean, É. (2013). Entrepreneurial personality: The role of narcissism. Personality and Individual Differences, 55(5), 527-531.

McClelland, D.C. (1961). The Achieving Society. Princeton, NJ: D. Van Norstrand Co Inc,

Nasip, S., Amirul, S.R., Sondoh Jr, S.L. \& Tanakinjal, G.H. (2017). Psychological characteristics and entrepreneurial intention: A study among university students in North Borneo, Malaysia. Education + Training, 59(7/8), 825-840.

Nguyen, C. (2018). Demographic factors, family background and prior self-employment on entrepreneurial intention-Vietnamese business students are different: why? Journal of Global Entrepreneurship Research, 8(1), 1-17.

Nowiński, W., \& Haddoud, M. Y. (2019). The role of inspiring role models in enhancing entrepreneurial intention. Journal of Business Research, 96, 183- 193.

Prakash, D., Jain, S., \& Chauhan, K. (2015). Supportive government policies, locus of control and student's entrepreneurial intensity: a study of India. Journal of Global Entrepreneurship Research, $5(1), 26$.

Prodan, I., \& Drnovsek, M. (2010). Conceptualizing academicentrepreneurial intentions: An empirical test. Technovation, 30(5-6), 332-347.

Quan, X. (2012). Prior experience, social network, and levels of entrepreneurial intentions. Management Research Review, 35(10), 945-957.

Rahaman, M., A., Ali, M. J., Mamoon, Z. R. \& Asheq, A. A. (2020). Understanding the Entrepreneurial Intention in the Light of Contextual Factors: Gender Analysis. Journal of Asian Finance, Economics and Business, 7(9), 639-647. https://doi. org/10.13106/jafeb.2020.vol7.no9.639 
Robinson, P. B., Stimpson, D. V., Huefner, J. C., \& Hunt, H. K. (1991). An attitude approach to the prediction of entrepreneurship. Entrepreneurship Theory and Practice, 15(4), 13-32.

Rotter, J. (1966). Generalized expectancies for internal versus external control of reinforcement. Psychological Monographs, $80(1), 1-28$.

Ryan, J.C., Tipu, S.A. \& Zeffane, R.M. (2011). Need for achievement and entrepreneurial potential: a study of young adults in the UAE. Education, Business and Society: Contemporary Middle Eastern Issues, 4(3), 153-166.

Segal, G., Borgia, D. \& Schoenfeld, J. (2005). The motivation to become an entrepreneur. International Journal of Entrepreneurial Behavior and Research 1(1), 42-57.

Stewart, W. H., Watson, W. E., Carland, J. C. and Carland, J. W. (1999). A proclivity for entrepreneurship: A comparison of entrepreneurs, small business owners, and corporate managers. Journal of Business Venturing 14(2), 189-214.

Tateh, O., Latip, H. A., \& Awang Marikan, D. A. (2014). Entrepreneurial intentions among indigenous dayak in sarawak, malaysia: an assessment of personality traits and social learning'. The Macrotheme Review, 3(2), 110-119.
Urbano, D., \& Aparicio, S. (2016). Entrepreneurship capital types and economic growth: International evidence. Technological Forecasting and Social Change, 102, 34-44.

Vuong, B. N., Phuong, N. N. D., Huan, D. D., \& Quan, T. N. (2020). A Model of Factors Affecting Entrepreneurial Intention among Information Technology Students in Vietnam. Journal of Asian Finance, Economics and Business, 7(8), 461-472. https://doi. org/10.13106/jafeb.2020.vol7.no8.461

Wardana, L. W., Handayati, P., Narmaditya, B. S., Wibowo, A., Patma, T. S., \& Suprajan, S. E. (2020). Determinant Factors of Young People in Preparing for Entrepreneurship: Lesson from Indonesia. Journal of Asian Finance, Economics and Business, 7(8), 555-565. https://doi.org/10.13106/jafeb.2020. vol7.no8.555

Zarei, E., Zainalipour, H., \& Shahraki, L. S. (2013). Relationship between achievement motivation and ambiguity tolerance with entrepreneurship among students in Hormozgan university. Journal of Educational and Management Studies, 3(2), 167-172.

Zeffane, R. (2013). Need for achievement, personality and entrepreneurial potential: A study of young adults in the United Arab Emirates. Journal of Enterprising Culture, 21(1), 75-105. 